\title{
Risk-related disclosure practices in the annual reports of Portuguese credit institutions: an exploratory study
}

This study assesses the risk-related reporting practices of 190 Portuguese credit institutions based on a content analysis of their individual annual reports for 2006. Risk-related disclosures are found to lack comparability because of different maturity time bands that report exposures to credit, market and liquidity risks; different VaR and sensitivity analysis assumptions; and different practices for reporting capital structure and adequacy. The mis-alignment of quantitatively-based disclosures and related narratives led to problems of relevance, reliability and understandability.

We assess the extent to which reforms of risk-related reporting practices in 2007 in International Financial Reporting Standards and the BASEL II Accord address each of the deficiencies identified. We highlight areas needing further reform and recommend that Portuguese supervisory authorities adopt more effective enforcement mechanisms to broker compliance with minimum mandatory risk disclosure requirements.

KEY WORDS: Financial, reporting, disclosure, risk, management, content, Portugal. 


\section{INTRODUCTION}

The global financial crisis [GFC] of 2008 has reinforced the importance for investors and regulators to subject the quality of risk-related disclosures in the banking sector to close scrutiny. Even before the GFC, the inadequacies of risk-related disclosures in annual reports had been a matter of public debate. In 2007 , Woods ${ }^{1}$ drew attention to variations in the level and usefulness of risk-related information disclosed by companies. In 2008, the Financial Stability Forum (FSF) emphasised that the banking sector often failed to disclose the magnitude of risk associated with bank products in a clear and easily accessible way, ${ }^{2}$ prompting observations that there was "a failure in confidence" in the financial system. ${ }^{3}$

Although new breadth has been brought to risk reporting practices by International Financial Reporting Standard (IFRS) 7 (Financial Instruments: Disclosures), the lack of transparency in risk reporting disclosures of banks that is found in periods prior to the adoption of IFRS $7^{4-16}$ has persisted in studies conducted after the adoption of IFRS $7 .{ }^{17-21}$ However, in these studies the sample sizes analyzed are usually small; and only a part of the broad array of financial institutions affected by the GFC (that is, banks) are studied. To address this, we analyze 190 Portuguese credit institutions [PCIs], including banks. ${ }^{22}$

Market-based measures (such as market capitalization or total assets) are an inappropriate means for evaluating the visibility of credit institutions. Although the subprime crisis of 2007 resulted in widespread increases in the total assets of financial institutions, ${ }^{17}$ in the aftermath of the GFC many reported that their loan books were worth much less than book value, even though governments continued to classify them as "well capitalized." 23 On the other hand, market "prices may not always reflect true fundamental values. (...) [And] a liquidity crunch can affect market prices."24 
Additionally, market prices only incorporate "investors' viewpoints on company performance, thus ignoring other crucial stakeholder groups" ${ }^{25}$ such as depositors, borrowers and regulators.

The present study uses the number of branches to proxy for the visibility of PCIs. The choice of this proxy is influenced by data showing that, since 2006, the number of branches of credit institutions per 100,000 inhabitants has been almost three times greater in Portugal than in European Common Law countries (UK, Ireland and Netherlands). Further, among European Latin countries, Portugal has the highest growth rate in number of bank branches. ${ }^{26}$ The consumer-oriented nature of PCIs implies an inherent coupling between their business practices and public interest. Greater levels of public visibility imply a greater level of stakeholders' interest, and a greater need to heed stakeholders' expectations. ${ }^{25}$ Therefore, one way to proxy these interactions (and the public visibility of these institutions) is through the number of branches they operate.

The present study focuses on the usefulness of mandatory and voluntary riskrelated disclosures in the individual annual reports for 2006 of 190 credit institutions registered by the Portuguese Central Bank. The four qualitative characteristics of financial statements, enunciated in the International Accounting Standards Board's conceptual framework, are invoked to assess usefulness: relevance, reliability, understandability and comparability. ${ }^{27}$ Two focal aspects of the study are first, riskrelated disclosures required in IFRS 7; and second, operational risk, capital structure and adequacy disclosures, and levels of adherence to Basel II (Pillar III) requirements.

Results reveal that the adoption of IAS/IFRS in Portugal has led to more riskrelated information being disclosed than required by the Portuguese Accounting Plan for the Banking Sector [PAPBS]. Transparency across the sampled companies was 
impaired by comparability difficulties, inability to understand narratives, failure of narratives to explain numerical disclosures, and lack of disclosure of all mandated riskrelated matters in annual reports. The transparency problems in Portuguese credit institutions in the pre-GFC period were very similar to those found in Anglo-Saxon studies. ${ }^{4,6,8-11,16}$

We contend that sub-optimal levels of mandatory risk-related will persist after the adoption of IFRS 7 and its recent amendments focusing on fair value and liquidity risk. Consequently, our findings should inform future attempts to improve accounting regulation. We argue that accounting, banking and financial market regulators should collaborate to require a consistent disclosure model that improves comparative financial information. The persistence of risk disclosure deficiencies reported after the adoption of IFRS 7 suggests that the G20 recommendations (that led to the Basel II Accord reforms, the Capital Requirements Directive [CRD], and IFRS 7 amendments) will lead to a socially desirable flow of information only if appropriate enforcement mechanisms are instituted to assure compliance with minimum disclosure requirements.

In the following section we develop an analytical framework and briefly contextualise the regulatory setting in Portugal. Thereafter, we explain our research method, describe the sample, and report results, conclusions and recommendations.

\section{ANALYTICAL FRAMEWORK}

\section{Regulatory background}

PCIs are supervised by accounting rules and reporting requirements issued by the Portuguese Central Bank. For listed companies, some risk-related corporate governance disclosures are required by the Portuguese Stock Exchange Committee (Comissão do Mercado dos Valores Mobiliários). Additionally, Article 66 of the Portuguese Companies' Code (Código das Sociedades Comerciais) requires companies to disclose 
their main risks and uncertainties in the management report. Although Article 66 focuses on financial risks, it also requires disclosure of information about environmental risks, operational risks, and risk management activities related to financial risks.

For financial years starting on January 1, 2005, Regulation 1606/2002 of the European Commission requires companies whose securities are traded on a regulated market to prepare consolidated accounts in accord with IAS. From 2005, the Portuguese Central Bank supervised the application of Regulation 1606/2002 in the banking sector. The accounting frame of reference from 2005 onwards was as follows:

a) In 2005, listed and non-listed companies (except for Mutual Agricultural Credit banks [MACBs]) in a regulated market were required to adopt adjusted IAS/IFRS or Instruction 4/96 (PAPBS) in their individual accounts. After January, 2006, they were required to adopt adjusted IAS/IFRS;

b) In 2005, MACBs were required to adopt Instruction 4/96 (PAPBS) in their individual accounts. In 2006, they were required to adopt Instruction 4/96 (PAPBS) or adjusted IAS/IFRS; and after January, 2007 they were required to adopt adjusted IAS/IFRS.

Therefore, in reporting risk-related information in 2006, PCIs (with the exception of MACBs) were required to adopt adjusted IAS/IFRS in their individual accounts and to comply with the following standards:

- IAS 1 (Presentation of Financial Statements) ${ }^{28}$

- IAS 30 (Disclosures in the Financial Statements of Banks and Similar Financial Institutions)

- IAS 32 (Financial Instruments: Presentation) ${ }^{29}$

- IAS 39 (Financial Instruments: Recognition and Measurement) ${ }^{30}$ 
- IAS 37 (Provisions, Contingent Liabilities and Contingent Assets).

IFRS 7 (Financial Instruments: Disclosures) became obligatory after January, 2007, although its adoption before 2007 was recommended.

\section{Minimum disclosure requirements}

Under the PAPBS the few disclosure requirements for risk matters relate to accounting policies (principally about impaired assets and provisions), credit risk (aging of assets according to maturity dates, details of impaired loans and advances), and liquidity risk (maturity analysis of current assets and liabilities). There is no requirement to disclose risk management information regarding objectives, policies and control structure.

Under IAS/IFRS the risk-related disclosure requirements, described in Table 1, are more extensive and demanding.

\section{(Insert Table 1 about here)}

Although disclosures are to be provided in the notes, there are instances of crossreferenced information being provided in the management report, in accord with $\S$ B6 (IFRS 7). Narrative information about financial risk management objectives and policies are to be presented in the notes in self-contained risk management sections (IAS 1.104-5). PCIs adopting either PASBS or IAS/IFRS have to disclose this kind of information in a self-contained section of the management report, as required by Article 66 of the Portuguese Companies' Code.

\section{Literature review}

Risk disclosure in corporate annual reports in the banking sector is under-researched. ${ }^{14}$ However, some studies have examined the importance of risk disclosure on the market discipline of risk taking in the banking industry. These studies confirm that greater disclosure enhances market discipline and that better risk management systems attract 
investors. ${ }^{31-33}$ Market discipline is defined as the "actions of shareholders, creditors and counterparties of banking companies [stakeholders] that can influence the investment, operational and risk-taking decisions of bank managers."

Due to the increasing complexity of the financial activities pursued by banks, and the consequent difficulties in properly monitoring and controlling financial companies, supervisory entities have relied on market discipline to assist their oversight. "Market monitoring",34 as a market discipline to limit banks' systemic risk is performed by stakeholders not covered by financial safety provisions. ${ }^{35}$ The greater the level and quality of disclosure, the greater the ability of stakeholders to monitor and assess changes in bank condition and to incorporate those assessments into a firm's security price if negative changes occur. This monitoring mechanism generates market signals that convey useful information to supervisors responsible for reducing a bank's risk exposure. $^{34}$

Usually, a decision to disclose information is based on a consideration of offsetting costs and benefits. This raises the question of whether disclosures should be mandatory or voluntary. Mandatory disclosures are desirable if voluntary disclosure falls short of the socially optimal level that assures effective market discipline. ${ }^{35}$ The banking industry has a sub-optimal disclosure level because of the costs of voluntary disclosure of private information. ${ }^{36}$ Over-disclosing does not compensate banks for the disclosure costs beyond those that are necessary, and so they are "typically cautious to go beyond minimal disclosure requirements." 35

Financial institutions have an array of stakeholders (owners, borrowers, depositors, regulators and managers). ${ }^{25}$ They provide necessary goods and services and their business practices are tied to the public interest. ${ }^{37}$ Therefore, increased public visibility demands extra care when addressing stakeholders' expectations through 
disclosure. Consequently, a greater level of legitimacy will be required through a reputation risk management process. ${ }^{38}$ Further, the opaque nature of banks' activities supports Diamond's ${ }^{39}$ argument about how disclosure can reduce the costly acquisition of information, and therefore, explain how it can be considered a socially desirable good. Greater levels of disclosure can reduce banking instability associated with socially undesirable "runs" on banks.

Consequently, supervisory and regulatory authorities impose socially desirable levels of mandatory risk information "as a necessary element of the government's prudential supervision of banks" ${ }^{35}$ because of the lack of incentives to voluntarily disclose. This helps assure the effectiveness of market discipline. Because higher levels of risk transparency enhance market stability and confidence. ${ }^{40}$

Studies of risk-related disclosures by banks have shown that market discipline or appropriate levels of supervisory oversight have been ineffective..$^{5,8,10-11,13-21}$ Standard setters have responded by developing high quality standards to improve opaque disclosures, remedy their deficiencies, and enforce supervisory mechanisms (see Basel II, second Pillar). Studies before and after the adoption of high quality standards have reported conflicting levels of effect on risk management disclosures. PriceWaterhouseCoopers ${ }^{12,21}$ found that the adoption of IAS/IFRS and IFRS 7 did not significantly affect the disclosure of risk management activities. However, Bischof ${ }^{17}$ and Woods et al. ${ }^{14}$ found otherwise. Some studies have also documented conflicting results in terms of disclosures of operational risk, and market risk. The Basel Committee on Banking Supervision, drawing on the Bank of International Settlements [BIS] ${ }^{41-43}$ and Helbok and Wagner, ${ }^{44}$ found increases in the extent and depth of voluntary operational risk disclosure. Avram and Skully ${ }^{4}$ found increases in disclosure quality, but a stable level of disclosure quantity. $\mathrm{KPMG}^{19,20}$ and PriceWaterhouseCoopers ${ }^{21}$ reported 
that banks disclosed information about VaR results. However, broader studies (such as by Yong et al. ${ }^{13}$ of 146 Asian Pacific banks; and Bischof ${ }^{17}$ of 153 European banks) reveal different results: only a small number of banks disclosed VaR results before and after the adoption of IFRS 7.

\section{Persistent deficiencies in risk-related disclosure}

Disclosure deficiencies reported before the adoption of IAS/IFRS and IFRS 7 have persisted after the adoption of those standards: disclosures have been found to lack transparency, be insufficient from a user's perspective, and be incomparable. ${ }^{14,15,16}$ Only a few US bank holding companies disclosed information for VaR by type of risk, backtesting, and stress testing, ${ }^{8}$ despite market risk disclosures increasing between 1994 and 2004. Only a third of risk disclosures by Asia Pacific banks followed Basel recommendations. ${ }^{13}$ Although most banks disclose information about how they measure and assess performance in managing market risks, only about one third reported quantitative information on market risk exposure and performance. VaR disclosures were not comparable. A low level of disclosure of credit, liquidity, and operational risks has been found too - such as lack of disclosure of detailed policies to mitigate credit and liquidity risk. VaR results have been found to pervasively and persistently overstate VaR results ${ }^{10,11}$, and overuse historical simulation. ${ }^{45}$

Boussanni et $a .^{5}$ documented a wide disparity in the level and extent of liquidity risk disclosures between European banks, concluding that disclosures about contingency planning and internal controls were insubstantive and incomplete. Further, risk disclosures were essentially qualitative. ${ }^{9}$ These results were confirmed by Ernst and Young, ${ }^{18}$ KPMG, ${ }^{19,20}$ and PriceWaterhouseCoopers. ${ }^{21}$ Other deficiencies were detected in credit risk disclosures (different time bands used in aging analyses of past due assets; lack of detailed description of associated collateral); and liquidity risk disclosures (use 
of generic liquidity risk management statements; misaligned liquidity risk exposure and qualitative disclosures regarding management strategies to deal with those exposures; and the absence of sensitivity analysis of liquidity risk exposure).

These studies found poor transparency features, including unclear communication of the risks being managed, ${ }^{16}$ misalignments between key risk topics, imbalances between qualitative and quantitative data, undue reliance on statistical estimates to create a false sense of quantitative precision, ${ }^{46}$ and non-compliance with minimum mandatory requirements. ${ }^{17}$

\section{Finance sector preparedness for risk disclosure}

Research from throughout the world reveals a high likelihood that managers and banks are ill-prepared to deal appropriately with risk exposures. In the USA a minority of banks used, or planned to use, in-house models of credit risk management. ${ }^{47}$ Most senior managers of Nigerian banks were not fully prepared to manage liquidity risk exposure and were not conversant with common methods of measuring and managing a bank's liquidity exposure. ${ }^{48}$ Spanish saving banks lacked good knowledge of the operational risk requirements of the Basel II Accord; lacked an efficient organisational structure through which to implement an advanced operational risk information system; and had information systems that were incapable of responding to Basel II requirements. ${ }^{49}$ Other surveys have reached similar conclusions. ${ }^{50}$ Despite a good understanding of risk and risk management, staff of banks in the United Arab Emirates could not prioritize their main risk efficiently. ${ }^{54}$ Generally, Islamic banks are moderately efficient in risk assessment and analysis, risk monitoring and identification ${ }^{55}$ — the techniques they use predominantly involve maturity matching, gap analysis and credit ratings. ${ }^{56}$ 
There needs to be stronger acknowledgement by senior managements that implementation of Basel II requirements will lead to a better understanding of a bank's risk profile. Inadequate risk management and corporate governance practices, and failure of financial regulators to supervise these practices have been identified as important causes for the banking crises in Ireland and Iceland. ${ }^{51,52}$ In 2008, a survey of leading banks around the world showed that ineffective risk governance, risk reporting, and firm-wide risk expertise, were major contributors to the GFC. ${ }^{53}$

\section{RESEARCH METHOD}

\section{Sample}

From a population of 298 companies with individual annual reports published in the Portuguese Central Bank database as at December 31, 2007 we drew a sample of 190 PCIs (Table 2). We excluded all Portuguese financial institutions (99 companies) and nine credit institutions (two financial holding companies with incomplete annual accounts for 2006; four MACBs that adopted IAS/IFRS in 2006; and one investment bank and two financial holdings that adopted PAPBS in 2006).

(Insert Table 2 about here)

\section{Method}

Content analysis was used to quantify the risk-related quantitative information and narrative information disclosed in the annual reports. All items identified as risk disclosures required by IAS 1, IAS 30, IAS 32, IFRS 7 and the third Pillar of the Basel II Accord were included. ${ }^{57}$ There were six risk disclosure categories, defined as:

- risk management objectives and policies: risk identification and definitions, risk management policies, and whether there was a comprehensive risk report. 
- credit risk: the potential that a bank borrower or counterparty will fail to meet its obligations in accordance with agreed terms. Indicated by the amount of credit risk exposure, past due and impaired assets, collateral held, and credit risk quality.

- market risk: the risk of losses in on-balance sheet and off-balance sheet positions arising from movements in market prices. Indicated by the amount of market risk exposure and internal/external risk measurement models. Risks subject to this requirement pertain to interest rate related instruments and equities in the trading book; foreign exchange risk and commodities risk throughout the bank.

- liquidity risk: the risk that a firm will be unable to efficiently meet expected and unexpected current and future cash flow and collateral needs without affecting its daily operations or financial condition. Indicated by the amount of liquidity risk exposure and discussion of funding policies.

- operational risk: the risk of loss resulting from inadequate internal processes, people and systems, from external events, or from the adaptation of information systems to Basel II requirements.

- capital structure and adequacy: the measure of banks' financial strength and stability. Indicated by capital structure and amounts of Tier 1, 2 and 3; capital adequacy for different types of risk exposure and capital ratios; and capital adequacy approaches adopted under Basel II.

A binary coding system was used in which a credit institution scored 1 if the item was reported and 0 otherwise. Such disclosure scoring is useful in measuring the extent of, and variations in, reporting practices. ${ }^{14} \mathrm{We}$ coded information about the location of disclosures in the annual report, narratives, and information included in 
graphs and tables. Content analysis of the entire sample was performed by the first author, informed by his prior coding of an initial sample of four annual reports with another (independently operating) coder. An inter-coder reliability test was undertaken ${ }^{58}$ to measure the scale of coding errors revealed a Scott's $p i=86 \%$ which is "an acceptable level of inter-coder reliability., ${ }^{, 59}$

\section{RESULTS}

\section{Accounting and risk management objectives and policies}

PCIs with the lowest frequencies of narrative disclosures about risk-related information are those in which Portuguese accounting rules were adopted (that is, the MACBs) (Table 3). These results corroborate the view that the adoption of IAS/IFRS has led to a greater amount of risk-related disclosure. ${ }^{14,17}$ However, the location of these disclosures is not uniform. Other commercial and investment banks and Credit Financial Institutions [CFIs] usually discuss risk in specific sections of the annual report. But, financial holding companies and other entities show lower levels. The information is dispersed throughout the annual report, impairing understandability. Similar results have been found for periods before and after the adoption of IFRS $7 .{ }^{14,16,19,21}$

(Insert Table 3 about here)

Another surprising result is the low frequency of disclosure of risk management policies and control structure in financial holding companies, despite extended disclosures at a consolidated level.

Of the PCIs that adopted IAS/IFRS in their individual annual reports, the highest level of disclosure was by other commercial banks, and investment banks, and CFIs. However, the quality of risk reporting practices varied widely. At one extreme, two commercial banks provided comprehensive risk reports. These defined and reported key risks, the overall control structure for each risk factor, the risk management policies 
followed, the risk measurement models used to assess each risk factor, and discussed some strategic objectives. At the other extreme, several entities merely indicated they had risk exposures but did not explain further — they only provided risk definitions or detailed the overall control structure. Moreover, there was a lack of clarity in risk management statements, consistent with previous research. ${ }^{16,19,21}$ This made it difficult to assess a company's risk appetite appropriately. There was no clear identification of key risks. Some companies used undefined financial jargon (such as Value-at-Risk, stress test, back test, and sensitivity analysis).

\section{Credit risk}

Except for financial holding companies, mandatory information required by IAS 30 and IAS 32 was provided by all PCIs (Table 4, Panel A). This included information about the size of credit risk exposure and past due and impaired financial assets, thereby helping to assure comparability, confirming research by PriceWaterhouseCoopers. ${ }^{21}$ However, understandability was impaired because narrative explanations of numerical information were less than expected.

(Insert Table 4 about here)

There were differences in the detailing of credit risk exposure and past due impaired financial assets. Disclosure of risk concentrations (by industry sector) was lower. The information most disclosed was aggregated information, possibly because it is less costly to produce than non-aggregated information, and has lower proprietary costs. Because of their inherent proprietary nature, and the pre-GFC period of analysis, the size of collateral and the discussion of credit risk exposure show lower and different levels of disclosure. There were no disclosures for renegotiated assets. Since these are voluntary disclosures, a possible explanation for the lower levels of disclosure is that 
banks are "typically cautious to go beyond minimal disclosure requirements." disclosure level for companies adopting Portuguese accounting rules (the MACBs) were lower than for those adopting IAS/IFRS. Despite this difference, the disclosures are consistent and comparable.

Among adopters of IAS/IFRS, there were higher levels of disclosure in other commercial and investment banks and CFIs, than in other entities. For commercial banks and CFIs there were higher levels of narrative explanation of risk exposure, past due/impaired assets, and credit risk quality. ${ }^{60}$ Levels of disclosure were higher than those found ${ }^{17}$ in European commercial banks after the adoption of IFRS 7. Moreover, the disclosures approximated IFRS 7 requirements, except for the size of collateral held and renegotiated assets. Commercial banks and CFIs also seemed to prepare their credit risk information according to Basel II rules, since credit risk information by type of credit exposure, geographic distribution, industry type, and residual contractual maturity, was at high levels.

Transparency flaws in credit risk disclosures are shown in Table 4 (Panel B). The PCIs who followed IAS/IFRS were inconsistent in the amounts of credit risk exposure they disclosed by industry sector and by maturing assets. Some PCIs indicated explicitly that the amounts disclosed included maturing and past due assets, whereas others indicated explicitly that the amounts disclosed only included maturing assets. In the worst case, no explicit information was provided, making it difficult to understand what amount was disclosed.

Table 4 (Panel B) also shows differences in the maturity/aged time bands used to disclose the amounts of credit risk exposure by maturing assets, and past due assets, respectively. The differences are in the maximum range in the qualitative groups, and 
different time bands for the prior/no prior year figures. Similar problems were detected in studies after the adoption of IFRS $7 .{ }^{19-21}$

\section{Market risk}

Table 5 (Panel A) shows a much lower level of market risk disclosure by companies that adopted Portuguese accounting rules (MACBs) than those that adopted IAS/IFRS.

\section{(Insert Table 5 about here)}

Among those companies that adopted IAS/IFRS, banks show the highest levels of disclosure compared to CFIs, financial holding companies and other entities. The results diverge for frequencies of presentation of the repricing gap and the use of maturity dates/repricing gap to measure exposure to interest rate risk. Thus, some PCIs do not disclose the amount of their exposure. Moreover, Table 5 (Panels A and B) shows lower frequencies on monetary results for $\mathrm{VaR}$ and sensitivity analysis compared to the use of these two techniques. This is consistent with Bischof ${ }^{17}$ and Yong et al. ${ }^{13}$, but only for other commercial and investment banks. Although our results are a little higher than those found in these two studies, they do not confirm findings of $\mathrm{KPMG}^{19,20}$ or PriceWaterhouseCoopers ${ }^{21}$ (where all banks disclosed VaR results). A plausible explanation is that the $\mathrm{VaR}$ disclosures are costly to prepare, complex to interpret, and inherently unreliable, thereby encouraging non-disclosure. ${ }^{6}$

The proprietary nature of VaR information prompts its withdrawal from annual reports to avoid gambling with a bank's reputation. ${ }^{10,35}$ Inconsistencies detected for commercial and investment banks were related to VaR, stress tests, back tests, and sensitivity analysis, consistent with prior studies. ${ }^{13-21}$ Although stress tests and backtests are essential to assess the reliability of VaR monetary values and help define risk profile 
more precisely, ${ }^{61}$ only two commercial banks with comprehensive risk reports disclosed results of such tests.

There was a prevalence of historical simulation to measure VaR. As Pritsker ${ }^{45}$ notes, the inadequacy of such simulations is that they "respond sluggishly to changes in conditional volatility, and respond to large price movements asymmetrically (...). Because of these deficiencies, errors in risk estimates accumulate through time and sometimes become very large (...) [such that] traditional backtests have little power to detect them." VaR and sensitivity results are also not comparable. Panel B of Table 5 shows differences in assumptions and parameters used (relating to methods, confidence level, holding periods, analysis period, basis point value, and period of impact). In some cases no information is provided.

Different maturity/repricing time bands were used by the other commercial and investment banks that presented a repricing gap table (Table 5, Panel B), impairing comparability. A repricing gap table is a naïve way of presenting interest rate risk exposure, unless accompanied by sensitivity results showing how a positive or negative parallel shift in the interest rate curve would affect the gap. Only one commercial bank with a comprehensive risk report disclosed this kind of information. The lack of objectivity diminished the understandability of risk information.

\section{Liquidity risk}

Table 6 (Panel A) shows that liquidity risk disclosures by companies adopting Portuguese accounting rules (MACBs) are lower (in level and quality) than for those adopting IAS/IFRS. MACBs did not disclose a liquidity gap analysis table but presented a separate maturity analysis for current assets and liabilities.

(Insert Table 6 about here) 
For PCIs that adopted IAS/IFRS, Table 6 (Panel A) demonstrates noncompliance with minimum mandatory requirements established by IAS 30 and IAS 32 . A sub-optimal level of liquidity risk disclosure was characterised by a lack of discussion about detailed policies for mitigating liquidity risk and few specific narratives on how liquidity risk is managed. Only half of the commercial and investment banks and CFIs disclosed their liquidity risk exposure using a maturity analysis table. Further, not all clearly stated the maturity concept used to build the gap analysis (Table 6, Panel B). Numerical and narrative disclosures were aligned poorly, consistent with prior research. ${ }^{5,13,19-21}$ Few companies clearly discussed their funding policies and any alignment with their liquidity risk exposure. Users would have to exert considerable effort to link exposures to funding policies and to determine the reasons for the adoption of those policies.

The other PCIs either did not disclose any information, or disclosed their maturity analysis separately (for specific items such as loans and advances, resources, derivatives, subordinated loans, investments held to maturity). Among the PCIs that disclosed a liquidity gap analysis, the information was inconsistent, because maturity time bands differed (Table 6, Panel B), consistent with KPMG. ${ }^{19,20}$ These practices make it difficult for users to assess banks' liquidity risk exposure appropriately or to build a liquidity gap table. Consequently, comparability across companies is rendered difficult.

\section{Operational risk}

Table 7 shows that only one commercial bank disclosed an amount for operational risk exposure. Only one commercial bank completed the Basel II adaptation process. Very low frequencies of operational risk management disclosure and risk exposure were made by MACBs compared to the rest of the PCIs surveyed. Other commercial and 
investment banks and CFIs disclosed more in terms of risk management policies, operational control structures, and operational risk exposures. These PCIs seem to be still adapting to Basel II requirements. Therefore, they are more inclined to address disclosure requirements regarding definitions and risk management policies in a selfcontained section of the management report and notes. Moreover, scattered throughout the management reports were disclosures about the priorities of institutions in implementing new information systems, in training workers, and in restructuring organizations. Because 2006 was a complex period of adaptation, and because this is voluntary information, it is justifiable that (for reasons of caution and reputation damage) those disclosures were mainly in the form of generic and imprecise narratives.

(Insert Table 7 about here)

\section{Capital structure and adequacy}

The highest level of disclosure for capital structure and adequacy was by banks (MACBs, other commercial and investment banks) (Table 8, Panel A). Possibly this was because their higher levels of public visibility increased the need for legitimation with customers by informing them of their ability to avoid a banking crisis. These reasons have been used to explain the objectives of capital adequacy requirements. ${ }^{62}$

(Insert Table 8 about here)

However, few PCIs included narrative disclosures that critically discussed the amounts calculated for total eligible capital value, impairing understandability. Six banks (other commercial/investment banks) disclosed the approaches they followed to assess capital adequacy, capital requirements for credit, market and operational risk, and total capital ratio, according to Basel II (Table 8, Panel A). Some signalled the adoption 
of more advanced approaches in the future - IRB for credit risk, internal models for market risk, and AMA for operational risk ${ }^{63}$ (Table 8, Panel B).

\section{CONCLUSIONS}

When compared to Portuguese accounting rules, the adoption of IAS/IFRS has brought a greater flow of risk-related information but has not assured increased transparency across the Portuguese banking sector, consistent with previous studies. ${ }^{21}$ The Portuguese banking system has prominent visibility as a consequence of the greater (relative) number of branches. The two commercial banks with the best risk reporting performance had the highest number of branches, and are listed on a regulated market (Euronext Lisbon) and on a foreign stock exchange market. However, among the PCIs with a lower number of branches (CFIs and other entities), transparency flaws were more intense compared to commercial banks, and previous findings. ${ }^{5,8,13-21}$

Among financial holding companies, there were low levels of disclosure because these institutions made extended disclosures at a consolidated level. Risk reporting practices among investment banks are similar to those of commercial banks. But, this is not explained by public visibility, because the number of branches of investment banks is much lower. However, many investment and commercial banks belong to the same financial group, possibly explaining that similarity.

There was a lack of transparency in minimum binding disclosure requirements for market risk, liquidity risk and risk management objectives and policies - similar to the levels found in research studies before the adoption of IFRS $7 .{ }^{5,8,10,13-16}$ A lack of transparency was found too in voluntary disclosures (for example, of operational risk, capital structure and capital adequacy). Only credit risk disclosures presented optimal levels of mandatory compliance, similar to the findings of Frolov ${ }^{7}$ and KPMG. ${ }^{19,20}$ Assuming usefulness to investors is a direct function of attaining qualitative 
characteristics of relevance, reliability, understandability, and comparability, our findings for PCIs that have adopted IAS/IFRS confirm previous research. ${ }^{4,5,7-21}$ As in other countries, transparency across companies was impaired by comparability difficulties. Breaches of the other three desired qualitative characteristics of financial statements were found too, reducing the usefulness of risk-related information in decision making. Users face considerable difficulty in capturing the appropriate risk profile of a credit institution and in comparing that profile across the sector.

The understandability of narratives was poor. This was compounded by a general lack of narratives to explain numerical disclosures. The result is a potentially increased probability of multiple interpretations by readers, due to the imprecision, vagueness and misleading nature of the statements made. Numerical risk disclosures were useful, but were not fully transparent. Many lacked reliability (for example, VaR statistics) because no stress tests or back tests assured those statistics under different scenarios. They lacked comparability across companies too because of differing disclosure practices, and were unlikely to be understood fully because of non-alignment with narrative explanations. Users do not know if the information is bad news or good news, because no further information is usually given. Where given, it is dispersed throughout the annual report.

Although we did not analyse risk disclosures after the IFRS 7 became operational, other studies ${ }^{17-21}$ have confirmed that such adoption did not guarantee transparency, or assure the effectiveness of market discipline. Considering these flaws and the causes of the GFC, attempts have been made to reinforce market stability and confidence. The Larosiére Report ${ }^{64}$ proposed a recommended basis for the European Union [EU] position at the G20 meeting in London in 2009, where the agenda of regulatory reform included enhancing regulation and strengthening transparency; 
reinforcing international cooperation and integrity in financial markets; and reforming the International Monetary Fund, Word Bank and multilateral development banks. ${ }^{65}$ The G20 agreed to proposals to refine bank capital standards; mitigate bank procyclicality; implement a bank leverage ratio standard; ${ }^{66,67}$ adopt voluntary executive compensation standards; centralize over-the-counter derivatives trading and clearing; develop cross-board financial institutions contingency plans; ${ }^{68}$ and converge IFRS and US GAAP. ${ }^{69,70}$

In 2009, the BIS revised the Basel II market risk framework by introducing higher capital requirements to capture the credit risk of complex trading activities. The BIS stressed the value-at-risk requirement to reduce the procyclicality of minimum capital requirements. Pillars 2 and 3 were reinforced in securitisation, off-balance sheet exposures, and trading activities. Following endorsement of the reform programme by the Financial Stability Board and the G20, the BIS issued consultative proposals to improve the quality of the Tier 1 capital base. This was intended to promote the buildup of capital buffers in good times so that they could be drawn on in periods of stress. The BIS requires more forward-looking provisioning to help reduce procyclicality, and to introduce a minimum liquidity standard for internationally active banks. In terms of disclosures, banks will be required to disclose information about their regulatory capital elements.

The EU has adopted this recommendation. The Capital Requirements Directive [CRD] was amended in 2009 (Directive 2009/111/EC, European Parliament and Council) regarding large exposures, hybrid capital, liquidity risk management, and securitisation. However, to date, Portugal has not enacted any law to implement this directive. BIS reforms relating to trading book, re-securitisation and remuneration are under negotiation in CRD III. CRD IV, which is open for public consultation, canvasses 
proposals regarding the building of a high quality capital base, strengthening risk coverage, mitigating procyclicality and discouraging leverage (as well as strengthening liquidity risk requirements and forward-looking provisioning for credit losses).

Following from the G20 conclusions, IFRS 7 was amended to introduce a threelevel hierarchy for fair value measurement disclosures that requires entities to provide additional disclosures about the reliability of fair value measurements. The amendments also clarify and enhance existing requirements for the disclosure of liquidity risk by seeking qualitative disclosures to support quantitative data, and a stronger alignment between liquidity risk exposure and related risk management policies.

However, the IFRS 7 amendments were insufficient to overcome disclosure deficiencies detected in studies before and after the initial adoption of IFRS 7. Potential reasons are that IAS/IFRS are not aligned with the way financial companies manage risk, and they are not bank-oriented standards. ${ }^{21}$ IAS/IFRS focus only on financial risk, ignoring other kinds of risks (such as operational risks) faced by banks. This misalignment can culminate in the dispersal of risk reporting practices throughout an annual report, rendering them incomparable, and imprecise. ${ }^{14-16,19,21}$ Furthermore, the principles-based nature of IAS implies the use of professional judgement, leading to non-comparable reporting practices. Thus, risk disclosure regulators should collaborate to require a consistent disclosure process that will improve the level of comparability across the sector. ${ }^{71}$ Future amendments to IFRS 7 should consider issues about the specific time bands to be used regarding the maturity of assets and credit risk exposures, past due assets, disclosure of sensitivity to stressed market conditions for market risk, and sensitivity analysis/stress tests of liquidity.

Several studies have shown low levels of compliance with IAS/IFRS in the first year of adoption. ${ }^{72,73}$ This can be a possible explanation for the low levels of disclosure 
found in the present study. Ball et al. ${ }^{74}$ and Bradshaw and Miller ${ }^{75}$ concluded that formal harmonization does not necessarily lead to a complete material harmonization, ${ }^{76}$ but that it depends on rule enforcement in the regulatory environment. ${ }^{75}$ Consequently, "the extent to which accounting rules influence [accounting quality among non-finance companies] (...) depends on how well these rules are enforced."77 Enforcement mechanism procedures "monitor the compliance of the financial information with the applicable reporting framework and taking the appropriate measures in case of infringements discovered in the course of enforcement." ${ }^{, 78}$ Efforts to improve selfenforcement mechanisms in terms of corporate governance structures (e.g., audit committees), quality of statutory audits, and institutional oversight systems (e.g., Portuguese Central Bank, and Portuguese Stock Exchange Committee) are critical in achieving minimum disclosure requirements. ${ }^{79}$ If better risk reporting is mandated, this will encourage companies to implement better risk management systems and better risk reporting should ensue. ${ }^{80}$

Our findings should be assessed with regard for the limitation that the content analysis method (used widely across many disciplines) does not allow readily for indepth qualitative analysis of disclosures. Further, the potential for information about risk to be provided in media other than annual reports (such as interim reports, pressreleases, web sites, analyst meetings or prospectuses) should not be overlooked. Future research could investigate factors likely to lead to better risk-related disclosures of ownership structure, and board of directors' composition. 


\section{REFERENCES AND NOTES}

(1) Woods, M. (2007) Significant information gap that required regulators' attention. Financial Times. London (UK), 26 September, p.14.

(2) Financial Stability Forum (2008) Report of the Financial Stability Forum on enhancing market and institutional resilience. Follow-up on implementation, October.

(3) Heap, A. (2008) Risk transparency in the aftermath of the credit crisis. Corporate Finance Review 12 (4): 30-35.

(4) Avram, K.J. and Skully, M. (2007) Australian banks' disclosure of operational risk. Monash Business Review 3 (2): 1-9.

(5) Boussanni, A., Desrochers, J., and Préfontaine, J. (2008) Liquidity risk financial disclosure: the case of large European financial groups. International Business \& Economics Research Journal 7 (7):47-56.

(6) Chipalkatti, N. and Datar, V. (2006) The relevance of value-at-risk disclosures: evidence from the LTCM crisis. Journal of Financial Regulation and Compliance 14 (2): 174-184.

(7) Frolov, M. (2006) Bank credit risk disclosure in Japan. Journal of Banking Regulation 7 (3/4): 221-242.

(8) Hirtle, B. (2007) Public disclosure, risk, and performance at bank holding companies. Federal Reserve Bank of New York. Staff Report 293, July.

(9) Linsley, P.M., Shrives, P.J. and Crumpton, M. (2006) Risk disclosure: an exploratory study of UK and Canadian banks. Journal of Banking Regulation 7 (3/4): 268-282.

(10) Pérignon, C., Deng, Z.Y. and Wang, Z.J. (2008) Do banks overstate their valueat-risk? Journal of Banking and Finance 32 (5): 783-794. 
(11) Pérignon, C. and Smith, D. (2010) The level and quality of value-at-risk disclosure by commercial banks. Journal of Banking and Finance 34 (2): 362377.

(12) PriceWaterhouseCoopers (2006) Accounting for change: a survey of banks' 2005 IFRS annual reports. London.

(13) Yong, H.H.A., Chalmers, K. and Faff, R. (2005) Asia Pacific banks' derivative and risk management disclosures. Asian Review of Accounting 13 (1): 15-44.

(14) Woods, M., Dowd, K. and Humphrey, C. (2008a) Market risk reporting by the world's top banks: evidence on the diversity of reporting practice and the implications for international accounting harmonisation. Spanish Accounting Review 11 (2): 9-42.

(15) Woods, M., Dowd, K. and Humphrey, C. (2008b) The value of risk reporting: a critical analysis of value-at-risk disclosures in the banking sector. International Journal of Financial Services Management 3 (1): 45-64.

(16) Woods, M. and Marginson, D. (2004) Accounting for derivatives: an evaluation of reporting practice by UK banks. European Accounting Review 13 (2): 373-390.

(17) Bischof, J. (2009) The effects of IFRS 7 adoption on bank disclosure in Europe. Accounting in Europe 6 (1-2): 167-194.

(18) Ernst and Young (2008a) IFRS 7 in the banking industry. London.

(19) KPMG (2008) Focus on transparency: trends in the presentation of financial statements and disclosure of information by European banks. London.

(20) KPMG (2009) Focus on transparency: trends in the presentation of financial statements and disclosure of information by European banks: 2009. London.

(21) PriceWaterhouseCoopers (2008) Accounting for change: transparency in the midst of turmoil. A survey of banks' 2007 annual reports. London. 
(22) Three quarters of our sample is composed by banks. They are special because of their interconnectedness. A collapse of one institution creates a wave of uncertainty among the others. [The Economist (2008) Paradise lost. Vol. 387, 17 May]. Consequently, other entities that are not classifiable as banks (but which pursue similar activities) were affected also by the GFC. The present study seeks to understand the risk-related reporting practices of credit institutions as a whole.

(23) Weil, J. (2009) Next bubble to burst is banks' big loans values. Bloomberg, 12 August, http://bloomberg.com/apps/news?pid=email_en\&sid=a04oVutXQybk, accessed 14 August 2009.

(24) Laux, C. and Leuz, C (2009) The crisis of fair value accounting: making sense of the recent debate. Accounting, Organizations and Society 34 (6/7): 826-834.

(25) Branco, C.B. and Rodrigues, L.L. (2008) Social responsibility disclosure: a study of proxies for public visibility of Portuguese banks. The British Accounting Review 40 (2): 161-181.

(26) European Central Bank (2010) Structural indicators for the EU banking sector, Frankfurt.

(27) Information is relevant if it has predictive and confirmatory values. Reliable information must be free from material error and bias and faithfully represent reality. Information is understandable if complex and relevant matters are not excluded from financial statements because they are too difficult for readers to understand. Therefore, efforts to include definitions, glossaries or other forms of detail would improve understandability. Comparability can be assessed over time or across different companies in terms of relative financial position, performance, and risk profiles (such as the amount of disclosure, the maturity profile of assets, measurement models, and risk management policies). 
(28) The amendment to IAS 1, adopted by Regulation 108/2006 of the European Parliament (concerning disclosure of information necessary to evaluate an entity's objectives, policies and processes for managing capital), was mandatory for periods beginning on or after 1 January 2007. Earlier application was encouraged.

(29) In 2006, IAS 32 included disclosure requirements about financial risks. IFRS 7 superseded IAS 30 and amended IAS 32 concerning disclosures of risk-related issues. IFRS 7 relates only to financial risks and requires a deeper level of disclosure than in the previous IAS 30 and IAS 32.

(30) IAS 39 was not considered because this study only explores international accounting requirements related to disclosure.

(31) Nier, E. and Baumann, U. (2004) Disclosure, volatility, and transparency: an empirical investigation into the value of bank disclosure. Federal Reserve Bank of New York. Economic Policy Review 10 (2): 31-45.

(32) Nier, E. and Baumann, U. (2006) Market discipline, disclosure and moral hazard in banking. Journal of Financial Intermediation 15 (3): 332-361.

(33) Sensarma, R. and Jayadev, M. (2009) Are bank stocks sensitive to risk management? The Journal of Risk Finance 10 (1): 7-22.

(34) Bliss, R.R. and Flannery, M.J. (2002) Market discipline in the government of U.S. bank holding companies: monitoring vs. influencing. European Finance Review 6 (3): 361-395.

(35) Frolov, M. (2007) Why do we need mandated rules of public disclosure for banks? Journal of Banking Regulation 8 (2): 177-191.

(36) Verrecchia, R.E. (2001) Essays on disclosure. Journal of Accounting and Economics 32: 97-180. 
(37) Miles, R.H. (1987) Managing the corporate social environment. Prentice-Hall, New Jersey.

(38) Bebbington, J., Larrinaga, C. and Moneva, J.M. (2008) Corporate social reporting and reputation risk management. Accounting, Auditing and Accountability Journal 21 (3), pp. 337-361.

(39) Diamond, D.W. (1985) Optimal release of information by firms. Journal of Finance 40 (4): 1071-1094.

(40) Credit risk is of particular importance because it is "regarded as the main contributor to a bank's overall risk profile". [Khambata, D. and Hirche, S. (2002) Off-balance-sheet credit risk of the top 20 European commercial banks. Journal of International Banking Regulation 4 (2): 107-122]. Risks related to off-balance sheet instruments (where credit risk is important) is a good example of information that would improve transparency. Before the GFC, the complexity of these instruments, their off balance sheet nature, and poor regulation often meant that very little information was disclosed by banks. ${ }^{3}$

(41) Bank for International Settlements (2001) Public disclosures by banks: results of the 1999 disclosure survey. Basel Committee on Banking Supervision, April.

(42) Bank for International Settlements (2002) Public disclosures by banks: results of the 2000 disclosure survey. Basel Committee on Banking Supervision, May.

(43) Bank for International Settlements (2003) Public disclosures by banks: results of the 2001 disclosure survey. Basel Committee on Banking Supervision, May.

(44) Helbok, G. and Wagner, C. (2006) Determinants of operational risk reporting in the banking industry. Journal of Risk 9 (1): 49-84.

(45) Pritsker, M. (2006) The hidden dangers of historical simulation. Journal of Banking and Finance 30 (2): 561-582. 
(46) Ernst and Young (2008b) Navigating the crisis: a survey of the world's largest banks. Ernst and Young, London.

(47) Fatemi, A. and Fooladi, I. (2006) Credit risk management: a survey of practices. Managerial Finance 32 (3): 227-233.

(48) Toby, A. (2006) Empirical study of the liquidity management practices of Nigerian banks. Journal of Financial Management and Analysis 19 (1): 57-70.

(49) Flores, F., Bónson-Ponte, E., and Escobar-Rodríguez, T. (2006) Operational risk information system: a challenge for the banking sector. Journal of Financial Regulation and Compliance 14 (4): 383-401.

(50) Ernst and Young (2006) Global Basel II survey: Basel II business impact. Ernst and Young, London.

(51) O’Sullivan, K.P.V. and Kennedy, T. (2010) What caused the Irish banking crisis? Journal of Financial Regulation and Compliance 18 (3): 224-242.

(52) Sigurjonsson, T.O. (2010) The Icelandic bank collapse: challenges to governance and risk management. Corporate Governance 10 (1): 33-45.

(53) Hashagen, J., Harman, N., Conover, M., and Sharma, J. (2009) Risk management in banking: beyond the credit crisis. Journal of Structured Finance 15(1): 92-103.

(54) Al-Tamini, H.A.H. and Al-Mazrooei, F.M. (2007) Bank's risk management: a comparison study of UAE national and foreign banks. Managerial Finance 32 (3): 227-233.

(55) Hassan, A. (2009) Risk management practices of Islamic banks of Brunei Darussalam. Journal of Risk Finance 10 (1): 23-37.

(56) Ariffin, N.M., Archer, S. and Karim, R.A.A. (2009) Risk in Islamic banks: evidence from empirical research. Journal of Banking Regulation 10 (2): 153-163. 
(57) These were largely in terms of disclosure requirements for capital structure and adequacy, and operational risk. The Basel II Accord became mandatory for PCIs after January, 2007. However, PCIs have been preparing for its adoption since 2004.

(58) Krippendorff, K. (2004) Content analysis: an introduction to its methodology. Sage, London.

(59) Hackston, D. and Milne, M. (1996) Some determinants of social and environmental disclosures in New Zealand companies. Accounting, Auditing and Accountability Journal 9 (1): 77-108.

(60) Widely used credit risk quality indicators were: past due ratio, coverage ratio, non performing loans and loan-to-value. Their disclosure levels across the different PCIs are very different.

(61) Marcelo, A., Rodríguez, A. and Trucharte, C. (2008) Stress tests and their contribution to financial stability. Journal of Banking Regulation 9 (2): 65-81.

(62) Marini, F. (2008) Financial intermediation, monitoring, and liquidity. Oxford Economic Papers 60 (3): 440-461.

(63) The Basel II Accord proposed the following approaches to assess capital adequacy: standard approach (SA), internal ratings approach "IRB - foundation" or internal ratings approach "IRB - advanced" for credit risk; standard approach (SA) or internal models approach for market risk; and basic indicator approach (BIA), standard approach (SA) or advanced measurement approach (AMA) for operational risk.

(64) European Commission (2009) The De Larosière report. The high-level group on financial supervision in the EU, Brussels. 
(65) European Bank Committee (2009) EU newsletter for the European Banking Committee, 10: March, 17.

(66) The Finance Professional's Post (2010) The G20 agenda for regulatory reform. 14 April, http://post.nyssa.org/nyssa-news/2010/04/the-g20-agenda-forregulatory-reform.html, accessed 15 August 2010.

(67) The Basel Committee is responsible for this task. Target dates range from December 2010 until December 2012.

(68) The FSB is responsible for this task. Target dates range from March 2010 until December 2012.

(69) The IASB is responsible for this task. The target date is June 2011.

(70) After G20 endorsement of 20 recommendations to address information gaps (described in a report The Financial Crisis and Information Gaps), IOSCO published a report (Asset Backed Securities (ABS) Disclosure Principles) to guide securities regulators who are developing or reviewing their regulatory disclosure regimes with respect to public offerings and listings of ABS. IOSCO is considering further work on collateralized debt obligation. [Financial Stability Board (2010) The financial crisis and information gaps: progress report, action plans and timetables. Switzerland].

(71) Recent changes in the IASC Foundation Constitution are intended to improve the involvement of stakeholders (including prudential regulators and emerging markets). A new monitoring board of market regulators was created and more investors and analysts were included in the Standards Advisory Committee.

(72) Carlin, T.M. and Finch, N. (2010) Resisting compliance with IFRS goodwill accounting and reporting disclosures: evidence from Australia. Journal of Accounting and Organizational Change 6 (2): 260-280. 
(73) Carlin, T.M., Finch, N. and Laili, N.H. (2009) Goodwill accounting in Malaysia and the transition to IFRS: a compliance assessment of large first year adopter. Journal of Financial Reporting and Accounting 7 (1): 75-104.

(74) Ball, R., Robin, A. and Wu, J.S. (2003) Incentives versus standards: properties of accounting income in four East Asian countries. Journal of Accounting and Economics 36 (1/3): 235-270.

(75) Bradshaw, M.T. and Miller, G.S. (2008) Will harmonizing accounting standards really harmonize accounting? Evidence from non-US firms adopting US GAAP. Journal of Accounting, Auditing and Finance 23 (2): 233-263.

(76) Formal harmonization "refers to the way accounting standards are written: that is, to their legal or quasi-legal specification." Material harmonization "refers to the level of concordance exhibited by the actual practices of companies in implementing accounting standards." [Mustata, R. and Matis, D. (2007) Measurement of need for harmonization between national accounting standards and international financial reporting standards. Journal of International Business and Economics 7 (3): 23-46].

(77) Leuz, C., Nanda, D. and Wysocky, P. (2003) Earnings management and investor protection: an international comparison. Journal of Financial Economics 69 (3): $505-527$.

(78) Committee of European Securities Regulators (2003) Standard $N^{o} 1$ on financial information: enforcement of standards of financial information in Europe, CESR/03-073, March.

(79) In May 2010, Commissaire Barnier announced that agreement on the proposal on supervising reform is needed in order to create the European Systemic Risk Board and the European Supervisory Authorities. He also announced the adoption of a 
Green Paper on Corporate Governance in financial institutions to help address questions about how to manage risk effectively in financial institutions, and how to empower shareholders. [Barnier, M. (2010) Effective financial market regulation after Pittsburg: achievements and challenges. Keynote Speech: Delivering on the EU's G20 commitments. International Conference, Federal Ministry of Finance, Berlin].

(80) Solomon, J.F., Solomon, A. and S.D. Norton (2000) A conceptual framework for risk disclosure emerging from the agenda for corporate governance reform. The British Accounting Review 32 (4): 447-478. 
Table 1: Minimum disclosure requirements before and after the adoption of IFRS 7

\begin{tabular}{|c|c|c|}
\hline Risk Category $^{\mathrm{a}}$ & $\begin{array}{l}\text { Before adoption of IFRS } 7 \\
\text { (IAS 1, IAS } 30 \text { and IAS 32) }\end{array}$ & $\begin{array}{l}\text { After adoption of IFRS } 7 \\
\text { (IAS 1, IFRS 7) }\end{array}$ \\
\hline Generic $^{b}$ & $\begin{array}{l}\text { Basis of preparation of financial } \\
\text { statements } \\
\text { Specific accounting policies used } \\
\text { (such as the basis of measurement) } \\
\text { Description of financial risk } \\
\text { management objectives and policies }\end{array}$ & $\begin{array}{l}\text { Basis of preparation of financial } \\
\text { statements } \\
\text { Specific accounting policies used (such } \\
\text { as the basis of measurement) } \\
\text { Description of financial risk management } \\
\text { objectives and policies }\end{array}$ \\
\hline Credit & $\begin{array}{l}\text { Details of movements in any } \\
\text { allowance for impairment losses and } \\
\text { advances during the period } \\
\text { Aggregate amount of impairment } \\
\text { losses } \\
\text { Maximum credit risk exposures } \\
\text { Potential risk concentrations (e.g. by } \\
\text { industry type) }\end{array}$ & $\begin{array}{l}\text { Total credit risk exposure and quality } \\
\text { Analysis of aged past due non-impaired } \\
\text { assets } \\
\text { Analysis of individual impaired financial } \\
\text { assets } \\
\text { Collateral held or repossessed } \\
\text { Carrying amounts of renegotiated assets }\end{array}$ \\
\hline Market $^{\mathrm{c}}$ & $\begin{array}{l}\text { Interest risk exposure detailed by } \\
\text { contractual repricing or maturity dates } \\
\text { Nature and extent of off-balance sheet } \\
\text { instruments exposed to interest rate } \\
\text { risk } \\
\text { Repricing gap analysis } \\
\text { Sensitivity analysis of how risk } \\
\text { exposures are managed and controlled }\end{array}$ & $\begin{array}{l}\text { Detailed information about VaR models } \\
\text { (assumptions, parameters and limitations) } \\
\text { Sensitivity analysis for each type of } \\
\text { market risk. Description of the method, } \\
\text { assumptions and parameters used }\end{array}$ \\
\hline Liquidity & $\begin{array}{l}\text { Liquidity gap analysis of assets and } \\
\text { liabilities according to their maturity }\end{array}$ & $\begin{array}{l}\text { Maturity analysis for financial liabilities } \\
\text { Qualitative disclosures about how } \\
\text { liquidity risk is managed }\end{array}$ \\
\hline $\begin{array}{l}\text { Capital } \\
\text { Structure and } \\
\text { Adequacy }\end{array}$ & & $\begin{array}{l}\text { Description of what is managed as capital } \\
\text { Nature of capital requirements imposed } \\
\text { externally } \\
\text { Description of how capital requirements } \\
\text { are incorporated into management of } \\
\text { capital } \\
\text { Description of how managing capital } \\
\text { objectives being met }\end{array}$ \\
\hline \multicolumn{3}{|c|}{$\begin{array}{l}\text { a Disclosures for operational risks are voluntary. IAS/IFRS only regulate financial risks. There are no specific } \\
\text { disclosure requirements for operational risks. } \\
\text { b Article } 66 \text { of the Portuguese Companies Code requires companies to disclose in the management report their } \\
\text { financial risk exposures and financial risk management objectives and policies. Therefore, if specific risk-related } \\
\text { disclosures were found in the management report, these disclosures were considered mandatory. } \\
{ }^{c} \text { Market risks include interest rate risk, foreign exchange risk, equity risk and commodities risk. }\end{array}$} \\
\hline
\end{tabular}


Table 2: Portuguese Credit Institutions in the sample

Number of companies

Commercial Banks

- Mutual Agricultural Credit Banks [MACBs]

- Other

Investment Banks

$\begin{array}{ll}\text { Credit Financial Institutions [CFIs] } & 15\end{array}$

Financial Holding Companies $\quad 21$

$\begin{array}{ll}\text { Other Entities } & 13\end{array}$

\begin{tabular}{lr} 
Total & 190 \\
\hline
\end{tabular}

The Portuguese finance sector is composed of credit institutions and financial companies. DecreeLaw 298/92 defines credit institutions as "companies whose business is to receive deposits or other repayable funds from the public and to grant credits for its own accounts" (Article 2). Financial companies are "companies that are not credit institutions" (Article 5). This study deals only with risk-related reporting practices of credit institutions.

Because of the different business goals of banks, we categorized them as commercial banks and investment banks. ${ }^{17}$ Commercial banks deal with checking, savings, and money market accounts. They accept deposits and perform lending activities. Investment banks raise capital, trade securities and manage corporate mergers and acquisitions. Commercial banks are divided into Mutual Agricultural Credit Banks [MACBs], and Other banks. Only MACBs have adopted the PAPBS in their individual accounts according to Notice 1/2005 of the Portuguese Central Bank. All the other companies have adopted adjusted IAS/IFRS rules.

Credit Financial Institutions are regulated by Decree-Law 186/2002 and are very similar to banks. They focus on lending activities, but cannot receive deposits from the public.

Financial holding companies are registered by the Portuguese Central Bank. They hold and control equity shares of PCIs included in the sample. Notice 1/2005 of the Portuguese Central Bank also applies to financial holding companies whose subsidiaries are credit or investment companies. To be considered a financial holding company their subsidiaries should represent at least $50 \%$ of consolidated assets. However, the Portuguese Central Bank can propose other criteria.

Other entities deal with leasing, factoring, and mutual guarantee activities. They include investment companies and credit-purchase financing companies not classified as banks or credit financial institutions. 
Table 3: Portuguese Credit Institutions with narrative disclosures about risk-related information in risk management sections

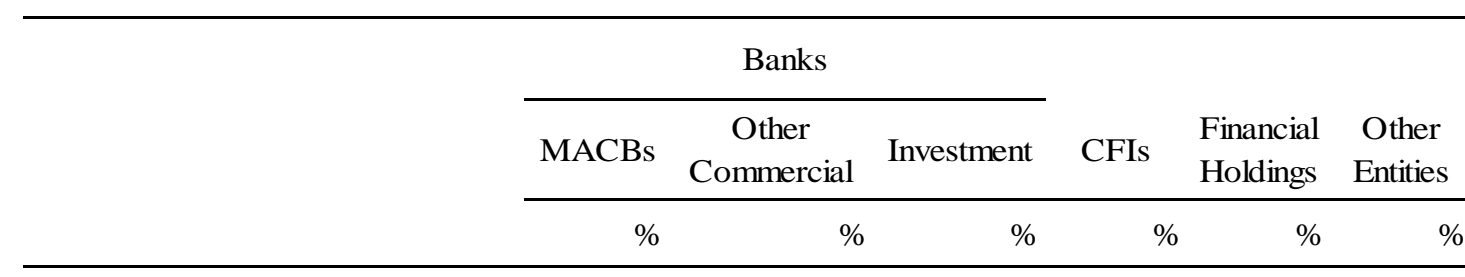

Risks identified

Key

Generic

Definitions
Other
0

0
23

73

82

27

Risk management policies followed

Credit risk
Market risk
Liquidity risk
Operational risk

0

0

0

91

82

Operational risk

0

Overall control structure

\begin{tabular}{|c|c|c|c|c|c|c|}
\hline Credit risk & 0 & 73 & 78 & 67 & 14 & 38 \\
\hline Market risk & 0 & 68 & 83 & 20 & 14 & 15 \\
\hline Liquidity risk & 1 & 59 & 67 & 27 & 10 & 15 \\
\hline Operational risk & 0 & 27 & 44 & 33 & 10 & 15 \\
\hline \multicolumn{7}{|c|}{ Risk management sections } \\
\hline Management report & 0 & 64 & 44 & 27 & 33 & 23 \\
\hline Notes & 0 & 91 & 100 & 80 & 52 & 54 \\
\hline
\end{tabular}


Table 4: Portuguese Credit Institutions with credit risk disclosures in annual reports

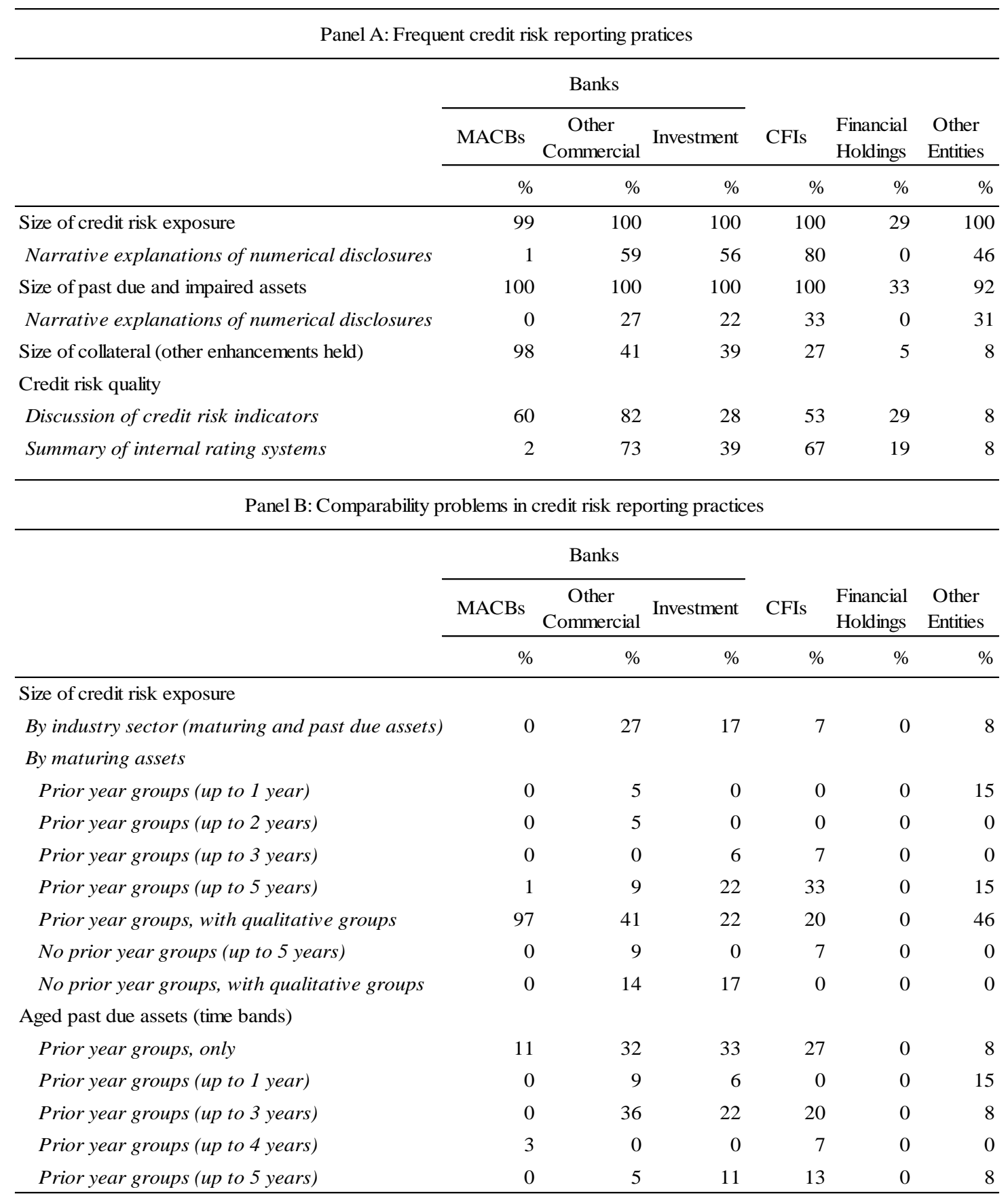


Table 5: Portuguese Credit Institutions with market risk disclosures in annual reports

\begin{tabular}{|c|c|c|c|c|c|c|}
\hline \multicolumn{7}{|c|}{ Panel A: Frequent market risk reporting practices } \\
\hline & \multicolumn{3}{|c|}{ Banks } & \multirow[b]{2}{*}{ CFIs } & \multirow[b]{2}{*}{$\begin{array}{l}\text { Financial } \\
\text { Holdings }\end{array}$} & \multirow[b]{2}{*}{$\begin{array}{l}\text { Other } \\
\text { Entities }\end{array}$} \\
\hline & MACBs & $\begin{array}{c}\text { Other } \\
\text { Commercial } \\
\end{array}$ & Investment & & & \\
\hline & $\%$ & $\%$ & $\%$ & $\%$ & $\%$ & $\%$ \\
\hline \multicolumn{7}{|l|}{ Market risk exposure } \\
\hline Foreign exchange risk exposure & 0 & 41 & 72 & 0 & 5 & 15 \\
\hline Interest rate risk exposure & 1 & 77 & 83 & 47 & 24 & 31 \\
\hline Measured by maturity dates/repricing gap & 0 & 50 & 56 & 13 & 5 & 31 \\
\hline Presentation of a repricing gap table & 0 & 36 & 33 & 13 & 0 & 23 \\
\hline Value-at Risk monetary results & 0 & 32 & 33 & 0 & 5 & 0 \\
\hline Sensitivity analysis monetary results & 0 & 27 & 6 & 7 & 0 & 0 \\
\hline \multicolumn{7}{|c|}{ Panel B: Comparability problems in market risk reporting practices } \\
\hline & \multicolumn{3}{|c|}{ Banks } & & \multirow[b]{2}{*}{$\begin{array}{l}\text { Financial } \\
\text { Holdings }\end{array}$} & \multirow[b]{2}{*}{$\begin{array}{l}\text { Other } \\
\text { Entities }\end{array}$} \\
\hline & MACBs & $\begin{array}{c}\text { Other } \\
\text { Commercial }\end{array}$ & Investment & CFIs & & \\
\hline & $\%$ & $\%$ & $\%$ & $\%$ & $\%$ & $\%$ \\
\hline \multicolumn{7}{|l|}{ Maturity/repricing time bands } \\
\hline Prior year figures, only & 0 & 0 & 0 & 13 & 0 & 0 \\
\hline Prior year figures (up to 2 years) & 0 & 0 & 6 & 0 & 0 & 0 \\
\hline Prior year figures (up to 3 years) & 0 & 5 & 0 & 0 & 0 & 0 \\
\hline Prior year figures (up to 5 years) & 0 & 5 & 17 & 0 & 0 & 0 \\
\hline Prior year figures (up to 7 years) & 0 & 5 & 0 & 0 & 0 & 0 \\
\hline Prior year figures (up to 20 years) & 0 & 5 & 0 & 0 & 0 & 0 \\
\hline Prior year figures, with qualitative groups & 0 & 18 & 6 & 0 & 0 & 23 \\
\hline No prior year figures (up to 15 years) & 0 & 5 & 0 & 0 & 0 & 0 \\
\hline \multicolumn{7}{|l|}{ Value-at-Risk assumptions } \\
\hline Use of Value-at-Risk & 0 & 45 & 72 & 0 & 10 & 0 \\
\hline Method used - risk metrics & 0 & 9 & 17 & 0 & 0 & 0 \\
\hline Method used - historical simulation & 0 & 18 & 28 & 0 & 10 & 0 \\
\hline Method used-MonteCarlo simulation & 0 & 9 & 6 & 0 & 0 & 0 \\
\hline Confidence level/Holding period & 0 & 0 & 0 & 0 & 0 & 0 \\
\hline $99 \%$ / 1 day & 0 & 9 & 6 & 0 & 5 & 0 \\
\hline $99 \% / 10$ days & 0 & 32 & 17 & 0 & 5 & 0 \\
\hline $99 \%$ / 22 days & 0 & 0 & 6 & 0 & 0 & 0 \\
\hline $99 \%$ / 90 days & 0 & 0 & 6 & 0 & 0 & 0 \\
\hline $99 \%$ / 2 weeks & 0 & 9 & 6 & 0 & 0 & 0 \\
\hline $95 \% / \ldots$ & 0 & 5 & 0 & 0 & 0 & 0 \\
\hline Use of stress test & 0 & 32 & 33 & 0 & 5 & 0 \\
\hline Use of backtests & 0 & 27 & 44 & 0 & 10 & 0 \\
\hline \multicolumn{7}{|l|}{ Sensitivity analysis assumptions } \\
\hline Use of sensitivity analysis & 0 & 45 & 50 & 7 & 19 & 0 \\
\hline Period of analysis - monthly & 0 & 9 & 11 & 0 & 0 & 0 \\
\hline Period of analysis - quarterly & 0 & 5 & 0 & 0 & 0 & 0 \\
\hline Period of impact (12 months, only) & 0 & 5 & 17 & 7 & 0 & 0 \\
\hline Basis point value used - $100 \mathrm{bvp}$ & 0 & 9 & 22 & 0 & 0 & 0 \\
\hline Basis point value used - $200 \mathrm{bvp}$ & 0 & 23 & 0 & 7 & 5 & 0 \\
\hline
\end{tabular}


Table 6: Portuguese Credit Institutions with liquidity risk disclosures in annual reports

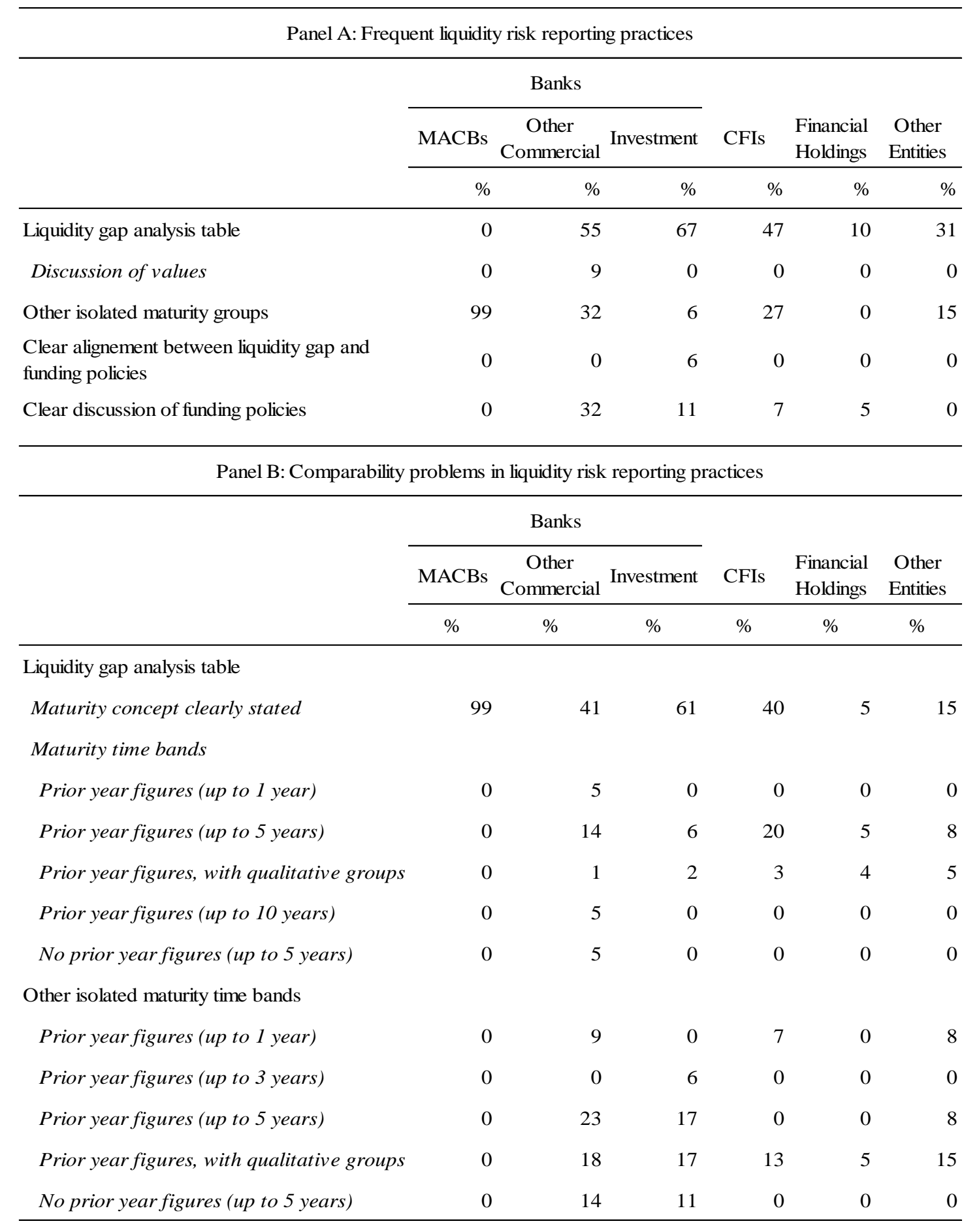


Table 7: Portuguese Credit Institutions with operational risk disclosures in annual reports

Frequent operational risk reporting practices

\begin{tabular}{|c|c|c|c|c|c|c|}
\hline & \multicolumn{3}{|c|}{ Banks } & \multirow[b]{2}{*}{ CFIs } & \multirow[b]{2}{*}{$\begin{array}{l}\text { Financial } \\
\text { Holdings }\end{array}$} & \multirow[b]{2}{*}{$\begin{array}{l}\text { Other } \\
\text { Entities }\end{array}$} \\
\hline & MACBs & $\begin{array}{c}\text { Other } \\
\text { Commercial }\end{array}$ & Investment & & & \\
\hline & $\%$ & $\%$ & $\%$ & $\%$ & $\%$ & $\%$ \\
\hline Operational risk exposure & 0 & 5 & 0 & 0 & 0 & 0 \\
\hline \multicolumn{7}{|l|}{ Clear statement of adaptation to Basel II } \\
\hline Adaptation of information systems & 3 & 41 & 28 & 20 & 19 & 8 \\
\hline Adaptation completed & 0 & 5 & 0 & 0 & 0 & 0 \\
\hline
\end{tabular}


Table 8: Portuguese Credit Institutions with capital structure and adequacy disclosures in annual reports

\begin{tabular}{|c|c|c|c|c|c|c|}
\hline \multicolumn{7}{|c|}{ Panel A: Capital struture and adequacy reporting practices } \\
\hline & \multicolumn{3}{|c|}{ Banks } & \multirow[b]{2}{*}{ CFIs } & \multirow[b]{2}{*}{$\begin{array}{l}\text { Financial } \\
\text { Holdings }\end{array}$} & \multirow[b]{2}{*}{$\begin{array}{c}\text { Other } \\
\text { Entities }\end{array}$} \\
\hline & MACBs & $\begin{array}{c}\text { Other } \\
\text { Commercial }\end{array}$ & Investment & & & \\
\hline & $\%$ & $\%$ & $\%$ & $\%$ & $\%$ & $\%$ \\
\hline \multicolumn{7}{|l|}{ Capital structure } \\
\hline Accounting structure & 100 & 100 & 100 & 100 & 100 & 100 \\
\hline Tier 1 amount & 2 & 14 & 0 & 0 & 0 & 0 \\
\hline Tier 2 amount & 5 & 27 & 0 & 7 & 10 & 0 \\
\hline Tier 3 amount & 0 & 0 & 0 & 0 & 5 & 0 \\
\hline Total eligible capital value & 48 & 41 & 6 & 13 & 10 & 0 \\
\hline Discussion about composition & 6 & 23 & 0 & 7 & 10 & 0 \\
\hline \multicolumn{7}{|l|}{ Capital adequacy } \\
\hline Discussion of capital adequacy approach & 0 & 5 & 6 & 0 & 0 & 0 \\
\hline Capital requirements for credit risk & 0 & 9 & 6 & 0 & 0 & 0 \\
\hline Capital requirements for market risk & 0 & 5 & 0 & 0 & 0 & 0 \\
\hline Capital requirements for operational risk & 0 & 5 & 0 & 0 & 0 & 0 \\
\hline Total capital ratio & 63 & 77 & 67 & 33 & 43 & 8 \\
\hline Tier 1 ratio & 11 & 41 & 28 & 7 & 29 & 0 \\
\hline Tier 2 ratio & 0 & 9 & 0 & 0 & 0 & 0 \\
\hline Total capital ratio according to Basel II & 0 & 9 & 6 & 0 & 5 & 0 \\
\hline \multicolumn{7}{|c|}{ Panel B: Adoption of capital adequacy approches proposed by Basel II requirements } \\
\hline & \multicolumn{3}{|c|}{ Banks } & & \multirow[b]{2}{*}{$\begin{array}{l}\text { Financial } \\
\text { Holdings }\end{array}$} & \multirow[b]{2}{*}{$\begin{array}{c}\text { Other } \\
\text { Entities }\end{array}$} \\
\hline & MACBs & $\begin{array}{c}\text { Other } \\
\text { Commercial }\end{array}$ & Investment & CFIs & & \\
\hline & $\%$ & $\%$ & $\%$ & $\%$ & $\%$ & $\%$ \\
\hline \multicolumn{7}{|l|}{ Capital adequacy approaches to be adopted } \\
\hline \multicolumn{7}{|l|}{ Credit risk } \\
\hline Standard approach (SA) & 1 & 23 & 11 & 0 & 10 & 8 \\
\hline Internal ratings based approach (IRB) & 0 & 27 & 17 & 20 & 10 & 0 \\
\hline \multicolumn{7}{|l|}{ Market risk } \\
\hline Standard approach & 1 & 0 & 6 & 0 & 0 & 8 \\
\hline Internal models approach & 0 & 14 & 0 & 13 & 0 & 0 \\
\hline \multicolumn{7}{|l|}{ Operational risk } \\
\hline Basic indicator approach (BIA) & 1 & 14 & 6 & 0 & 0 & 0 \\
\hline Standard approach $(S A)$ & 0 & 23 & 6 & 0 & 0 & 8 \\
\hline Advanced measurement approach (AMA) & 0 & 18 & 6 & 13 & 10 & 0 \\
\hline
\end{tabular}

